\title{
THE PLANNING OF TOURISM ON RURAL AREAS: THE STAKEHOLDERS' PERCEPTIONS OF THE BOTICAS MUNICIPALITY (NORTHEASTERN PORTUGAL)
}

\author{
Paula Remoaldo ${ }^{1}$, Isabel Freitas ${ }^{2}$, Olga Matos ${ }^{3}$, Hélder Lopes ${ }^{4}$, \\ Sara Silva ${ }^{5}$, Maria Dolores Sánchez Fernández ${ }^{6}$, \\ José Cadima Ribeiro ${ }^{7}$, Vitor Ribeiro ${ }^{8}$
}

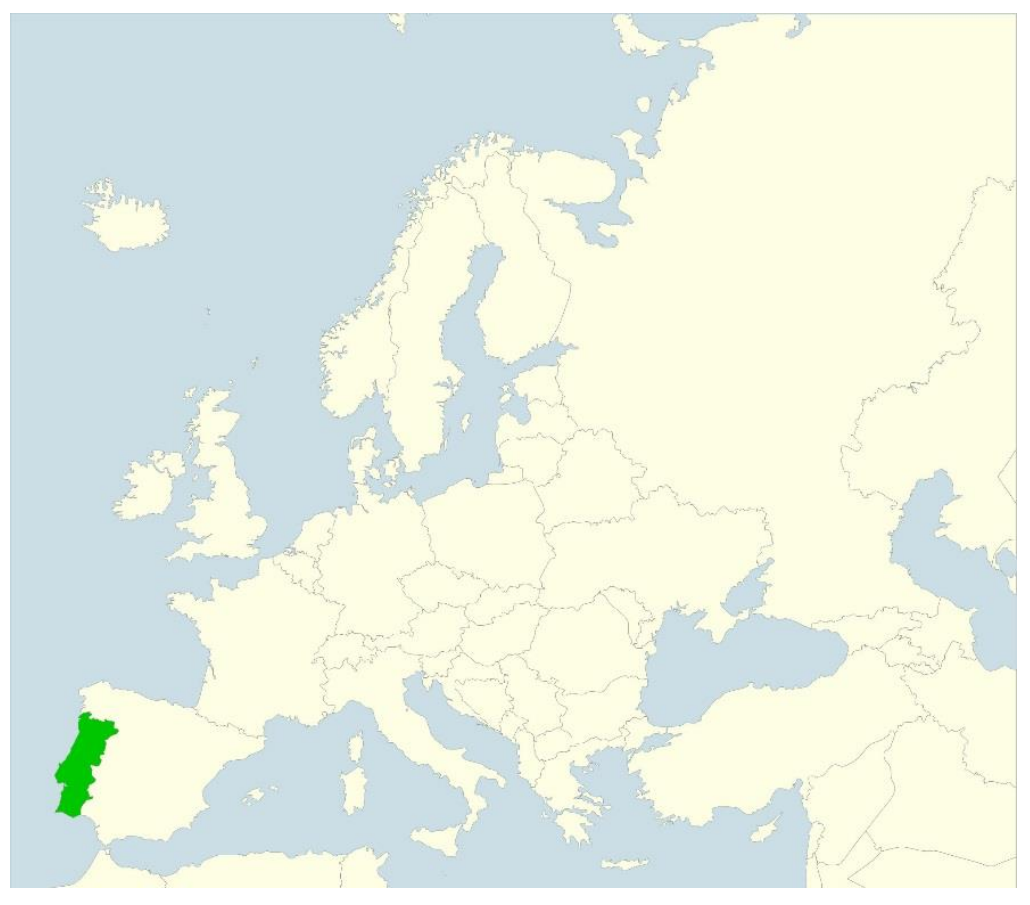

\footnotetext{
1 Ass. Prof. Paula Remoaldo, PhD., Laboratory of Landscape, Heritage and Territory, University of Minho, Lago de Paço, 4704-553 Braga, Portugal, e-mail: paularemoaldo@gmail.com

2 Ass. Prof. Dr. Isabel Maria Marinho Vaz de Freitas, Departamento de Territorio, Património e Cultura, Universidade Portucalense, Rua Dr. António Bernardino de Almeida 541, 4200-072 Porto, Portugal, e-mail: ifc@uportu.pt

3 Ass. Prof. Olga Maria Pinto de Matos, School of Technology and Management, Polytechnic Institute of Viana do Castelo, Rua Escola Industrial e Comercial de Nun' Álvares 34, 4900-347 Viana do Castelo, Portugal; e-mail: omatos@estg.ipvc.pt

${ }^{4}$ MSc. Hélder Tiago da Silva Lopes, Laboratory of Landscape, Heritage and Territory, University of Minho, Lago de Paço, 4704-553 Braga, Portugal, e-mail: htsltiago@gmail.com

${ }^{5}$ Sara Catarina Gomes da Silva, Laboratory of Landscape, Heritage and Territory, University of Minho, Lago de Paço, 4704-553 Braga, Portugal, e-mail: sara.catarina.g@gmail.com

${ }^{6}$ Ass. Prof. María Dolores Sánchez-Fernández, PhD., Faculty of Economics and Business, University A Coruña, Rúa de Maestranza 9,15001 A Coruña, Spain; e-mail: maria.msflores@gmail.com

${ }^{7}$ Prof. José António Cadima Ribeiro, PhD., Department of Economics, University of Minho, Campus de Gualtar, 4710057 Braga, Portugal, e-mail: jcadima@eeg.uminho.pt

8 Prof. Aux., Vitor Patricio Rodrigues Ribeiro, PhD., Department of Geography, University of Minho, Campus de Azurém, 4800-058 Guimarāes, Portugal, e-mail: vitor.geografia@gmail.com
} 
Abstract: Most of the strategies developed to "save" rural territories in Europe have not been successful. One of their main problems has been the adoption of the top-down paradigm when approaching the development of those territories. Portugal is a good example of the difficulty in adopting a bottom-up paradigm. The main objective of this paper is to present the perceptions of the local (including the residents) and regional stakeholders acting at Boticas, regarding the set of resources available and the development of the tourism industry. Boticas is a northern Portuguese, rural lowdensity municipality. In capturing those perceptions, the research contributes to the establishment of a more integrated and innovative development strategy and thus, a more capable strategy for profiting from the potential associated with the growth of the tourism industry that has been experienced recently in Portugal. The adoption of a mixed-method was suggested for evaluating these resources and capturing the perceptions of the tourist potential by different stakeholders. Empirical data was collected through a survey of 373 of its residents and 25 interviews conducted with local and regional actors, further supported by an inventory of the cultural resources and their capacity for visits. We conclude here that, residents tend to have a very positive perception of tourism development, and indeed, their perceptions largely met those of other stakeholders.

Keywords: Rural Development; Tourism Planning; Perceptions; Resources; Tourist Attributes; Stakeholders.

\section{Introduction}

In the last decade, a new rural development paradigm emerged, based on endogenous development processes, which is where territory resources and capabilities are assumed to be the key drivers of local/regional development. This paradigm and the consequent planning process contradicts the top-down model, assuming a bottom-up approach instead. According to this last approach, national governors are supposed to act mostly as facilitators of rural development policies, while actions are carried out by local/regional public authorities that sustain a close relationship with the rural communities.

As mentioned, endogenous development focuses on the use of a given territory's local resources and on the local community's commitment towards its development. With this finding in mind and in order to contradict the installed devitalisation tendency faced by certain rural areas, the tourism industry can be a positive way to promote sustainable development of rural areas in Portugal. To attain that outcome, more collaborative planning is needed, where both residents and other local and regional stakeholders can play a more relevant role.

The present paper approached the integrated view held by residents and local and regional stakeholders of Boticas municipality (Northern Portugal) toward the resources and attributes of their territory, and the way they perceive the tourism industry as a potential contributor to local development. Starting there, this paper also contributes to the design of strategies that aim to develop the Boticas tourism potential based on the implementation of a collaborative and participative model of policy decision-making.

In the approach to the territory and its development strategy, the research team took two following research questions as a starting point: i) how do local and regional stakeholders perceive the resources and attributes of the Boticas municipality? and ii) what kind of strategies for planning and of local and regional development could be proposed using more collaborative and participative way of decision-making?

We believe this goal can be achieved by using a mixed-method that highlights the contributions of local and regional stakeholders as central actors on the process and gives them the possibility to evaluate the resources and attributes of their territory and express their commitment to its development. A survey was applied to 373 residents of the Boticas municipality and 25 interviews 
with local and regional actors were also conducted. Additionally, the research team conducted an inventorying of the tourist resources of the territory and its capacity of being visited. Data collected in this way was helpful to structure the survey and guidelines were used for the interviews conducted with qualified local and regional stakeholders. This same inventory was also useful for achieving a certain kind of "triangulation" when interpreting the results of the survey of residents and the conducted interviews.

To date, not much has been discussed in Portugal regarding strategies that can enable a more collaborative development of rural areas. Seemingly, the Boticas (Northeastern Portugal) case study can be an example that can be replicated in similar rural areas.

This investigation is part of a larger one, entitled Contributions of Sustainable Tourism in the Boticas Municipality (Northeastern Continental Portugal), which began in 2015 and whose main goals were: i) to make a diagnosis of the tourist potential of the Boticas municipality; ii) to identify the destination profile; iii) to assess the perceptions of different local stakeholders (residents, visitors, local and regional actors) toward tourism development and the viability of their active involvement in the industry; iv) to contribute to the implementation of a more participative and sustainable development of the municipality of Boticas and its neighbours; and v) to contribute to the improvement of the local community's welfare and the quality of visits to Boticas.

Until the present time, a diagnosis of the historical, cultural, demographic and economic characteristics of the municipality and of the region, was performed as a whole. The evolution of local tourism and the main accessibilities available in the territory was also studied. This helped the research team design the specific instruments needed to capture the perceptions of different stakeholders. The results attained allowed us to draw certain policy recommendations aimed at contributing to the establishment of a new tourism strategy for the territory.

The present paper is structured into four sections. In the first and second sections, a review of the literature on rural tourism is offered as well as its role in the development of rural spaces. Section 3 focuses on the study area (Boticas). After a brief presentation of that area, the methods that were adopted are described and the main results that were attained are presented, together with discussion. The final section presents conclusions and the limitations of the research.

\section{Using Territory Resources: One Approach to the Development of Rural Areas}

The concept of development is considered a polysemic concept (Landford, 2009) and development of the tourism industry must take this into consideration when being implemented in rural territories. On the other hand, tourism is a complex and evolving phenomenon (Williams et al., 2014), but it is the perfect industry for implementing a holistic approach. This has to do with the fact that tourism requires the contribution of various fields of activity, stemming from transports to accommodation and food services to leisure and cultural activities, among several others. Also because it is one of the most obvious forms of globalisation (McEwan, 2005).

In the tourism domain, Leiper's contribution (1979) was ground-breaking. His point of view emphasised the need to follow a systematic approach when looking at a destination and its attributes. According to Leiper, this was the only way to understand, in depth and in a more complete way, the destinations, their environment and tourist flows.

Later, Murphy (1985) emphasised the need for a more integrated approach to tourism planning at the local level. He argued that people must participate in the formulation and application of the defined policies.

This concept is also related to the concept of sustainable development, which was revived in the 1990s by Butler (1999). In fact, it received increased social visibility in this decade following the publication of the report entitled Our Common Future. According to the World Tourism Organisation (2013), sustainable tourism must take into full account its current and future economic, social and environmental impacts, addressing the needs of visitors, the industry, the environment and the host communities. 
It also aims to embrace the "(...) optimal use of environmental resources that constitute a key element in tourism development, maintaining essential ecological processes and helping to conserve natural heritage and biodiversity" (World Tourism Organisation. European Commission, 2013 , p. 17). One must also add, the need to respect the socio-cultural authenticity of host communities, as well as the conservation of the built and living cultural heritage.

In this context, rural tourism must be seen as an activity based on the resources of the territory and integrated via traditional cultural, economic and social activities (Ehrlich, 2010). In this sense, rural tourism must be seen as a proactive activity, based on the pro-activity of the sites and the relationship established between visitors and the local resources. Reinforcing, they can further leverage of the local economy to allow the development of activities that can generate wealth and guarantee attractiveness for visitors.

In rural areas where development and mechanisation has grown very quickly, it is very important to consider rural landscape preservation, which is connected to the communities that live in and have moved through those lands. The movement of communities through those territories has created habits, traditions and left material and immaterial assets that constitute the main identity of those territories today. The rehabilitation of rural heritage is also a form of rural development based on tourism. The recovery of old rural and industrial buildings which, in general, are in ruins (Cano et al., 2013), is an essential part of that rehabilitation process.

Crosby (2007) noted that structures cyclically suffer from deterioration and loss of quality and well-being. The same author (Crosby, 2007) states that these moments of loss are opportunities for reinventing, which also applies as well to the case of rural tourism. In fact, in the case of Boticas, the rural structures have contributed to some of the deterioration over the last years, culminating in a large loss of residents, leading to spaces of low population density and ageing, which then has contributed to further stagnation of the rural world. So, in order to take profit from resources and market opportunities and thereby enhancing development, it is necessary to develop strategies that clearly appropriate for the local realities (Crosby, 2007).

Over the past decades, we have witnessed the emergence of a new vision for the development of rural areas, based on a new development paradigm: the endogenous development paradigm. This type of development is based on three principles: valorisation of endogenous resources; a bottom-up model; and the establishment of priority actions by the community, where the government only facilitates its implementation (Woods, 2011). Endogenous development is based on the use of resources through the valorisation of local economy and culture, where it is intended to affirm regional and local gastronomy, local festivities and immaterial heritage, ecotourism practices, reuse of local material heritage, re-qualification of artisanal industries and exploration of natural-landscape resources (Ray, 1998; Kneafsey, 2001; Fonte, 2008; Siebert, Laschewsky and Dosch, 2008; Kitchen and Marsden, 2009).

This type of policy, based on endogenous resources, is beneficial, seeing as local territories are endowed with different resources and capabilities - a major factor for attracting visitors and gaining added value in the market. In this regard, it is worth mentioning that contact with nature has gained prominence lately and tourists have been opting for rural spaces as a way of finding new emotions and sensations that traditional destinations no longer allow them to find (Abellán, 2008; Nylander, 2001). Besides seeking such contact with nature, culture, general infrastructures and local products are now essential factors in the development of rural tourism. In this way, local development can be achieved through an approach wherein local identity, together with quality, become the key drivers. In this regard, Hall et al. (2016), among others, recently pointed out the profound crises that the rural world is facing and the changes that it are still occurring.

Rural areas have been trying to reinvent themselves using cultural resources and the increasing recognition of the value of places as spaces of identity (Ducros, 2017). The traditional values cannot be forgotten, along with other elements. Of course, to achieve more equity and grant people commitment, the socio-economic benefits must be distributed fairly among all stakeholders. For that reason, the participation of all stakeholders is indeed needed (e.g., Butler, 1999; Hottola, 2009), together with strong political leadership, so as to ensure broad participation and consensus-building. 
As mentioned, over the years, some parts of the rural world have experienced great economic and social changes due to the exploitation and use of their territorial attributes, which have remained resilient in time and space (Lenao and Saarinen, 2015). In this regard, rural tourism has contributed to the development of these rural societies, taking profit from their singularities (Radac et al., 2012). Those benefits can be economic, social, and environmental, but Radac et al. (2012) claim that they have been mainly financial.

It cannot be stressed enough that the socio-economic benefits obtained from development must be distributed fairly among all stakeholders as a way of ensuring their commitment to the strategy being defined, as well as their participation during the planning process (e.g., Butler, 1999; Hottola, 2009). In the same sense, strong political leadership is necessary to ensure broad participation and consensus-building during the process of understanding rural tourism as an alternative to the more standardised or traditional tourism (Negrut and Vlad, 2016), which allows for a more personalised service offer.

Several studies show that there are a number of factors which influence the relative prosperity and economic performance of rural areas, as seen in countries such as England and the United States, according to the research results of Agarwal, Rahman and Errington (2009) and Isserman, Feser and Warren (2009), respectively. Nonetheless, endogenous rural development programmes are not absent of weaknesses, considering that, in some cases, the development policies are based on the concerns manifested by local elites and rural development professionals (Woods, 2007; Woods, 2011).

Rural development must be underpinned by an inside-outside duality. There are two main development perspectives: i) one based on the mobilisation of local actors and resources (internal dimension); and ii) another based on the consolidation and establishment of a sales brand, which requires the commitment of policymakers (external dimension) (Ray, 2006; High and Nemes, 2007; Bosworth et al., 2015). One of the strategies for accomplishing sustainable rural development can derive from the tourism industry.

In agreement with Aas, Ladkin, and Fletcher (2005), dialogue, cooperation and collaboration among and with local stakeholders minimises both risks and threats and develops practices that allow the preservation of the communities' cultural resources and the territories' natural resources. These dimensions are equally important to the development of tourism activities and thus, to the ongoing future development of the rural areas as a whole.

\section{The Role of Rural Tourism in the Development of Rural Areas}

Concerning rural tourism, this is not a recent practice, taking place, for example, in the early $20^{\text {th }}$ century in the UK and in the mountains of Bavaria and Tyrol (Cánoves et al., 2004; Haven-Tang and Sedgley, 2014; Lopes, 2016). Nevertheless, its relevance was practically residual until the 1960s (Moreno, 2008). As a result of its rapid expansion, tourism in rural areas is increasing tourism consumption, valuing real and quick experiences, and changing the patterns of contemporary agriculture (Haven-Tang and Sedgley, 2014). However, there are still few studies concerning tourism in rural territories, which explains the fragility of the strategies addressing its development in rural areas. It is worth keeping in mind that in order to be successful, strategies must address the resources, the needs and the development goals of each territory.

Many territories have been investing in tourism, viewing it as a panacea. Part of them have disregarded the specificity and requirements of the industry, and, surely, the rules of globalisation. This has given rise to poor tourism development outcomes.

In addition to the economic return that may be extracted from developing the industry, the bet of some rural areas on this segment of activity (rural tourism) is related to the small investment required for implementing certain services when compared to other tourism strategies (massive tourism), which normally involve large companies and chains of operators (Wilson et al., 2001). Indeed, rural tourism usually does not depend on external firms and decisions can (and should) be made based on a strict geographical scale (Shaw and Williams, 1994). The benefits of tourism in rural areas are usually reflected in services provided directly (e.g., attractions and hotels) or 
indirectly (e.g., gas stations and supermarkets) (Wilson et al., 2001) and, thus, the beneficiaries are, generally speaking, the local population.

Our vision on the issue is that implementing a more participative/collaborative planning of the industry can be essential to attain a more sustainable development path and contribute towards a more effective way, to the improvement of the local communities' welfare.

Approaching the territory from a holistic concept, and data for supporting analysis prior to decision making, must come from quantitative and qualitative sources and take into consideration the most relevant stakeholders.

The methodological diversity of the research conducted on tourism is well known, but usually there is a tendency to make use of a single method: either quantitative or qualitative. Besides, the analyses are based on: i) the use of multiple quantitative or qualitative methods; and ii) mixed methods (Molina-Azorín and Font, 2016).

For a long time, quantitative methods were the most common in tourism research, and even today, they continue to be the most relevant (Nunkoo, Smith and Ramkissoon, 2013). Recently, triangulation received an increased relevance (Opermann, 2000).

Triangulation can be defined as the use of two or more techniques to study the same research phenomenon, which may occur only at the level of research design, data collection or at the interconnection between them (Hussein, 2015). The use of triangulation in social sciences comes from the research of Campbell and Fiske (1959), through their idealisation of "multiple operation", in order to corroborate and validate research data.

In the present study, we have chosen to use both qualitative and quantitative data (QUAL and QUANT) since the beginning of our research, that is, we were concerned with collecting and using those two sources of data in the analysis (Molina-Azorín and Font, 2016).

Of course, evaluating the resources and attributes of a tourism destination is the first step if one aims to develop a comprehensive plan (Rivero, Martín, and Gallego, 2016).

As underscored before, understanding the perceptions and attitudes of residents is critical for getting their support in the development of the tourism industry and, particularly, for developing it in a sustainable way (Jackson, 2008; Nunkoo et al., 2013). In terms of what concerns Boticas, it was the first time that the residents were asked to participate in such a project and provide their perceptions on the issue.

If we want to go from a hallmarked decision-making process in the planning process to a more collaborative decision making process, the partnership between politicians and residents in the design of the strategies must become real. The preservation of several tourism resources depends a great deal on doing so. Besides, working with the population may decrease the risk of a rise of conflict between residents and visitors, among other possible negative impacts of tourism. In this regard, it is worth underscoring that residents are a major contributor to the quality of the tourist experience and are, of course, those agents of that territory that tend to interact more closely with any visitors.

\section{The Case Study Area - Boticas}

\subsection{A Brief Presentation on the Area}

The municipality of Boticas is located in the district of Vila Real, NUTS III of Alto Tâmega, NUTS II of Northern and North-Eastern region of Continental Portugal. The municipality has an area of $321.96 \mathrm{~km}^{2}$ and is subdivided into ten parishes and 52 small villages and different places with their own characteristics. According to the Typology of Urban Areas (TIPAU) in 2014, seven parishes are considered Medium Urban Areas (MUA) and three are considered Predominantly Rural Areas (PRA). In 2011, the population of the municipality of Boticas included 5,750 individuals, with 1,510 individuals residing in the central parish of Boticas and Granja ( $26.3 \%$ of the population in the municipality). 
Today, Boticas is composed of 10 parishes, divided into 52 small villages and different places such as: Alturas do Barroso, Beça, Bobadela, Boticas, Codessoso, Covas do Barroso, Dornelas, Pinho, São Salvador de Viveiro and Sapiãos.

In order to achieve the goals defined in this paper, quantitative and qualitative empirical approaches were taken. With the diagnosis in mind, a deep inventory and evaluation of the territory's endogenous resources was undertaken.

The primary sector of activity, mainly agriculture, guarantees the employment of $18 \%$ of the population. Despite the relative share of the tertiary sector (50.6\%), tourism activity does not provide a relevant contribution for the development of this territory. In this context, the tourism accommodation supply is very scarce. In 2013, Boticas registered 1,329 guests in hotels, and the average overnight stay was 1.4 nights (INE, 2014).

Keeping in mind the road system currently available now, Boticas is not far in time from the Portuguese coast and the major cities. Basically, it is $1 \frac{1}{2}$ hours far from the Francisco Sá Carneiro Airport (Oporto Airport) (Figure 1), and this shortening of time and distance is the result from the substantial improvements in road infrastructure that was introduced in the last two decades with the building of the A7, A11, and A24 motorways.

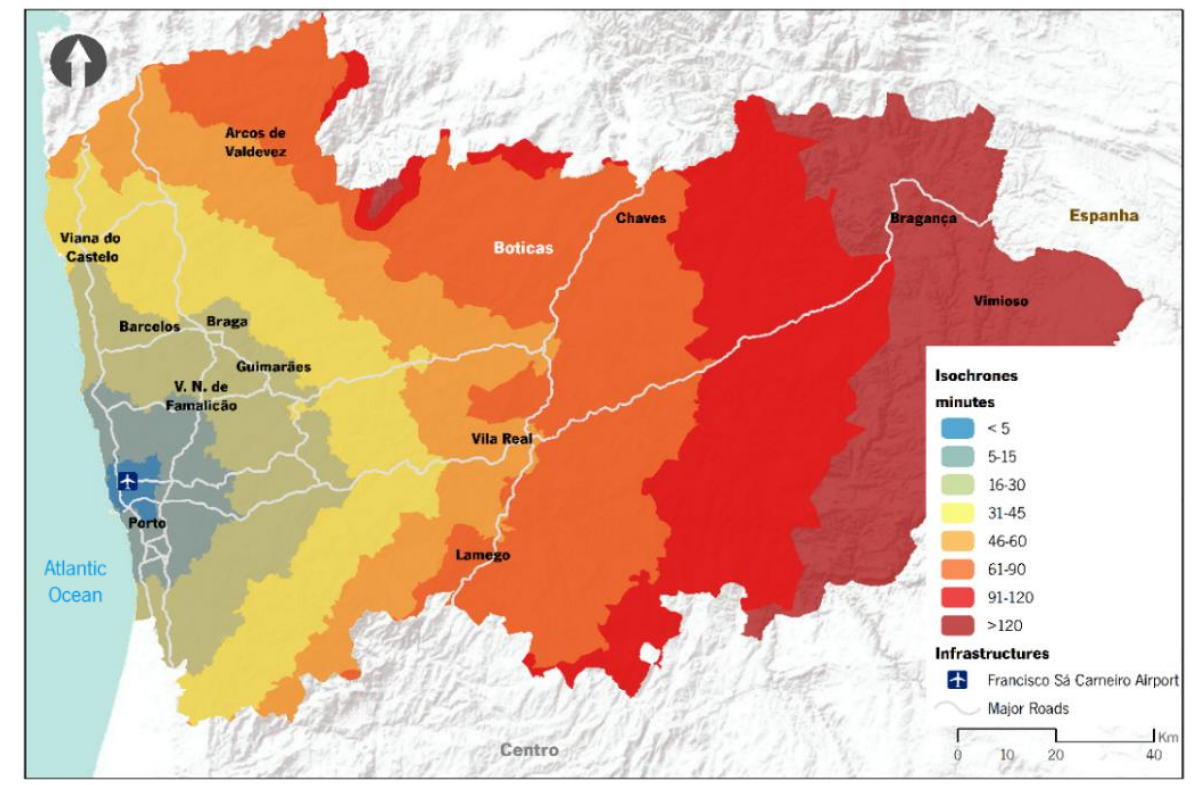

Fig 1. Time-distance (minutes) to the Francisco Sá-Carneiro Airport. Source: Authors' own elaboration

This territory presents a great diversity of resources. Boticas extends from the Tâmega river to the Alturas, Leiranco and Marcos mountains, contributing to a miscellany of sceneries.

The inventory of the territory's patrimonial resources allowed not only the highlighting of the built heritage, but also examining the state of conservation of that heritage. This inventory was the first phase of the process of capturing the value that local communities place on patrimony and its tourism potential. This assessment of the historical and the heritage potential of a territory's resources are a crucial factor when the planning the process for tourist activity (Rivero et al., 2016).

As a result of the fieldwork carried out in this case, the inventory and the location of immovable property resources were performed. From this resulted the catalogisation of a vast set of heritage assets, highlighting the settlements, churches and chapels, as well as a set of traditional houses and their annexes. In this case, we are referring to buildings such as community ovens, mills, fountains and spouts, which dominate the territory and constitute essential elements to be valued and explored (Figure 2). 


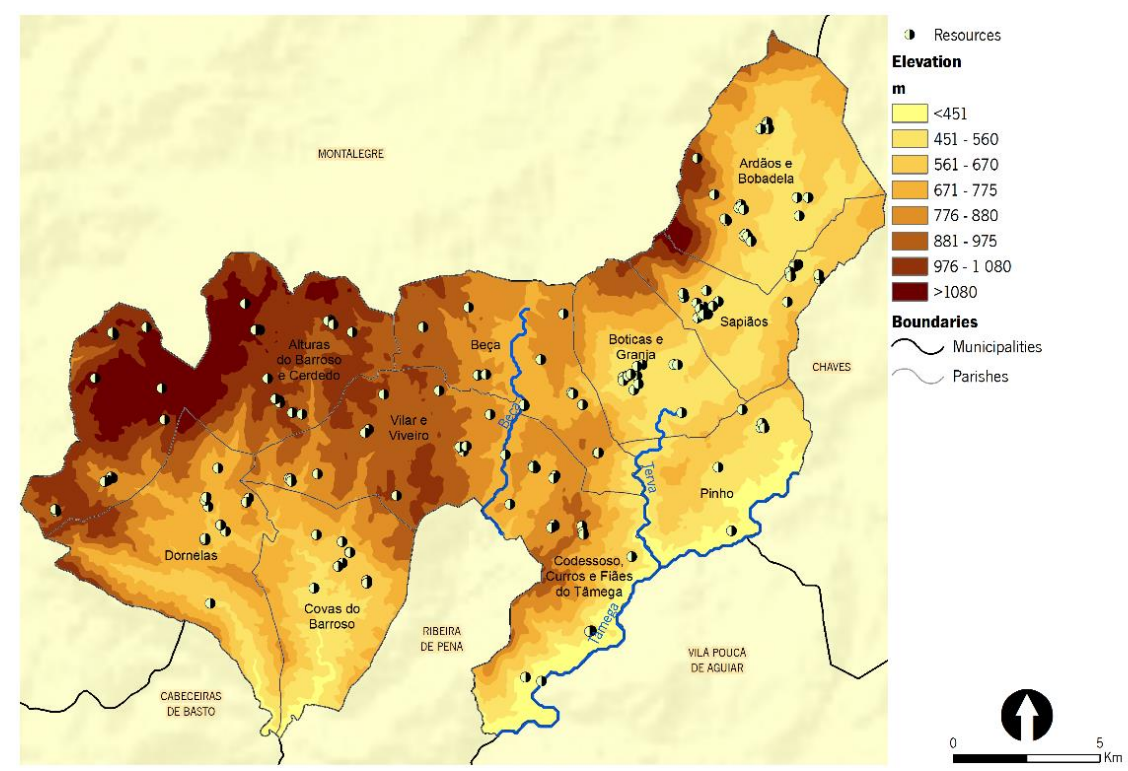

Fig 2. Heritage resources identified in the municipality of Boticas. Source: Authors' own elaboration, based on CAOP 2015

After a careful analysis, we can verify the presence of mainly religious buildings, such as churches and chapels, anthropomorphic graves, calvaries and crosses in a total of 36 occurrences, present in all of the municipality's parishes (Figure 3).

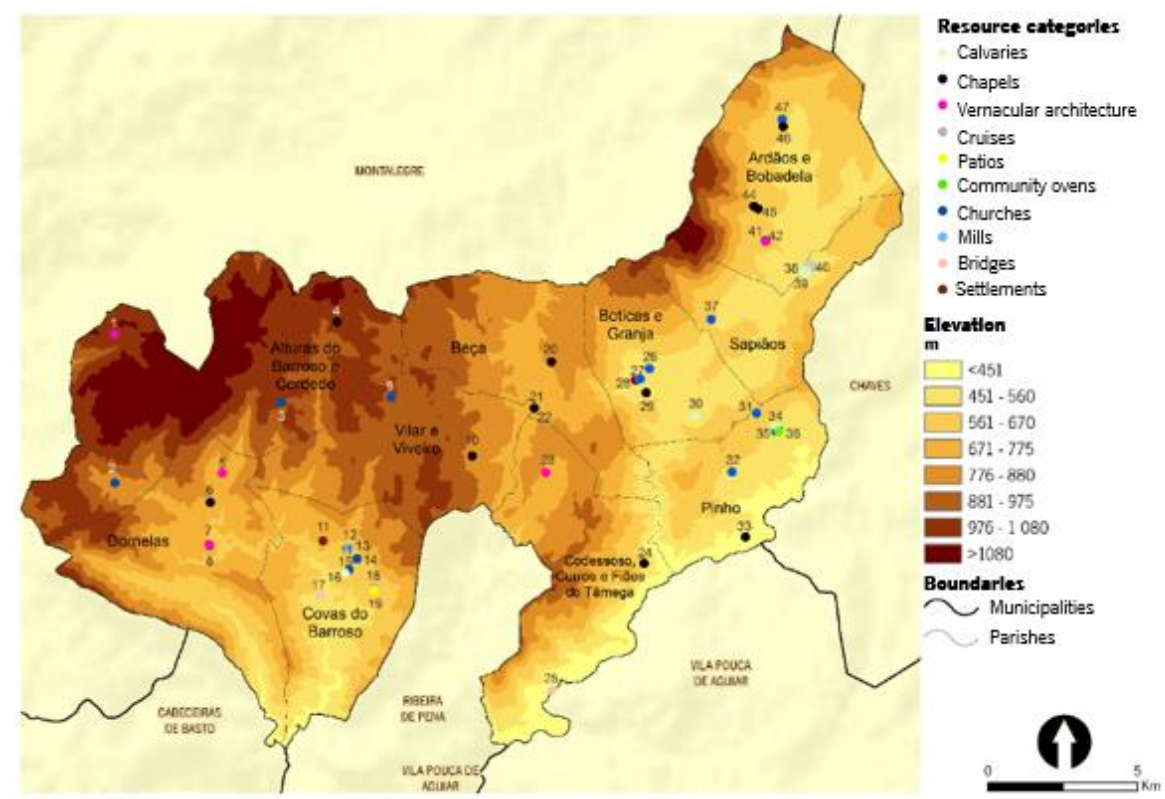

Fig 3. Heritage Resources with visiting potential. Source: Authors' own elaboration, based on CAOP 2015 and on fieldwork that took place between March and December 2016.

The houses and complexes of historical buildings constitute the second main occurrence, with a total of 7 examples, and are present in the parishes of Alturas do Barroso and Cerdedo, Dornelas, Bobadela and Boticas. In the parishes of Beça, Sapiãos, Codessoso and Covas do Barroso there are a total of 4 bridges (two are medieval and one is a wire bridge). Finally, there is one last exemplar of a pillory in Dornelas.

From a total of 180 inventoried resources, 48 were selected. This means that there is a low percentage of suitable assets, without the need for any kind of intervention, to be enjoyed and visited by tourists and with clear potential. It also shows a vast set of heritage with historical and cultural value in the municipality, with conservation problems and in need of intervention, along 
with other resources with low historical and cultural values, with signs of poor conservation and altered in their original form, thereby excluded from the list of tourist potential.

We may say that the territory has heritage resources, but the decision makers have to prepare them for touristic visits.

We can conclude that the resources identified with greater tourist potential are elements of religious built heritage, which indicates an intense religious community. Associated with the religious heritage, we must highlight the importance of intangible heritage, namely the annual religious festivals that involve the entire community and that are key elements of local identity, which allowed its preservation throughout many centuries.

However, although it is possible to conduct a tourist visit, there is still work to be done in order to protect these heritage resources, in order to respect international principles and norms included in letters and conventions.

\subsection{Methodology}

\subsubsection{Quantitative methodology}

\section{Survey applied to residents}

In order to obtain the residents' perception regarding the attributes of their territory and on the expected impacts of tourism development, a survey was applied. The questions raised to the Boticas residents addressed the following issues: how do local residents identify the main existing resources and how do they see tourism as a valid development strategy for their territory? Did they expect positive and negative impacts of tourism and of what nature? Were they available to play a role in the development of the tourism industry?

The survey was applied to the Boticas residents in 2016. A total of 737 questionnaires were distributed, and 453 were returned, which presented a response rate of $61.5 \%$. After eliminating those questionnaires containing incomplete answers, a total of 390 valid questionnaires were analysed.

The sample size took into account factors such as: i) the total population of the municipality; ii) its geographical distribution by parishes; and iii) the time-cost requirements necessary for completing the questionnaire (Gebremedhin and Tweeten, 1994). A sample was selected with a margin of error of $0.05 \%$ and a confidence level of $95.0 \%$.

The sample was determined based on the assumptions that the respondents were permanent residents of Boticas, over 15 years of age (age considered of mature cognition to respond Sekaran, 2003). The sample was proportionally stratified, based on the geographical distribution of the population of Boticas, age group and gender.

An estimated average time of 15 minutes was needed to fill in the questionnaire. A pre-test had been implemented in December 2015. The questionnaire had a total of five sections (from A to E), with a total of 23 questions. A five-point Likert scale was used in some questions (from 'strongly disagree' to 'strongly agree').

In section $A$ of the questionnaire, the global image of the municipality of Boticas was assessed, and in section B, the residents' perceptions of Boticas' tourism attributes and the places which they thought were worth visiting were analysed. In section $\mathrm{C}$, the residents' opinion on the development of the tourism industry in Boticas was assessed, followed by section $D$ that aimed to verify whether the respondent was available to take an active role in the development of a tourism strategy for Boticas (this last section is not commonly used). In the final section, the socio-demographic features of the respondents (age, gender, education, if he/she was born in the municipality or how long he/she has been living in Boticas) was inquired.

In the present paper, only the perceptions of the tourist attributes and the perceived effects of tourism development in the Boticas municipality were analysed.

The data was submitted to factor analysis and the statistical package SPSS (version 23.0) was used. The variables were submitted to different statistic measures and tests (Correlation matrix, 
Determining value, KMO, Bartlett's test of sphericity, Cronbach's Alfa, Communalities, Total variance explained and Rotated component matrix) in which the criteria specified in Table 1 were adopted.

Factor analysis is a technique that allows for the reduction of data to find homogeneous groups of variables. This study sought to find groups of variables with a common meaning, that is, endowed with a structural relationship. The technique was applied here with great statistical rigour in all its phases. This application implies eliminating those items that do not strictly comply with an adequate share for the explanation of the transformed variables (factors). From a strictly statistical approach, the use of this technique allows for getting answers to the research questions that were initially raised.

Tab 1. Factorial analysis: measures, tests and criteria. Source: Sánchez-Fernández (2014, p. 162)

\begin{tabular}{|l|l|}
\hline \multicolumn{1}{|c|}{ Measures and test } & \multicolumn{1}{c|}{ Criteria } \\
\hline Correlation matrix & There is a 60\% correlation $>0.3$ \\
\hline Determining value & Very low \\
\hline KMO & $>0.5$ (Verdu, 2002; Pérez, 2005) \\
\hline Bartlett's test of sphericity & Significance level (Sig) <0.05 (Bartlett, 1951) \\
\hline Cronbach's Alfa & Reliable scale $>0.7$ (Nunnally, 1978) \\
\hline Communalities & Tendency to 1 \\
\hline Total variance explained & Minimum range (60-80\%) (Wubneh, 1987; Wang, 2005) \\
\hline Rotated component matrix & $\begin{array}{l}\text { The specification of the number of factors was as expected, } \\
\text { seeing as a large quantity of information was returned (result } \\
\text { explicit by identifying the number of factors). }\end{array}$ \\
\hline
\end{tabular}

\subsubsection{Qualitative methodology}

Interviews with other stakeholders

Additionally and to complement the perceptions of the residents, 22 semi-structured interviews were conducted to local actors, complemented by 3 interviews to regional actors. These interviews took place between July and September 2016. The goal was to obtain the stakeholders' perceptions about the reality of the tourism industry in Boticas and its potential. Interviews were recorded and lasted approximately 20 minutes each, and the guidelines included questions i) related to the global image of Boticas, ii) the interviewee's position relative to tourism, and iii) his/her sociodemographic profile.

The analysis of the interviews utilised Content Analysis, which is an information processing technique that integrates any of the major types of logical procedures of investigation and serves different levels of empirical research (Silva and Pinto, 1987). It is important to remember that Content Analysis is "a technique that often has a complementary function in qualitative research, that is, it is used to 'triangulate the data obtained through one or two other techniques" (LessardHébert et al., 2012: 141).

The analysis was carried out in three phases: i) elaboration of the content analysis framework; ii) transcription; and iii) compilation of essential information according to the guidelines of that content analysis framework.

In the first phase, a table was prepared for each of the questions, selecting the various subcategories intended for each respondent's response, as well as several registration units, that is, the more relevant narratives of the various respondents. Finally, it was pointed out in each subcategory addressed throughout for the questions raised.

In the second phase, the recordings of all the interviews were transcribed in an integral way, producing 140 pages of running text. This was the most complex and time consuming phase. Finally, content analysis resulted in about 28 pages. 
In the present paper, a comparison between the perceptions of local and regional actors and those of the residents is presented.

\subsection{Presentation of Empirical Results and Discussion of Findings}

\subsubsection{Quantitative approach}

Table 2 displays basic descriptive statistics concerning the main socio-demographic characteristics of resident respondents. In fact, $54.2 \%$ of the survey's respondents were women and the most representative age range was from 25-64 years of age (67.6\%).

Tab 2. Social-demographic characteristics of the respondents. Source: Self-administrated questionnaire applied to residents between January and May 2016

\begin{tabular}{|c|c|c|}
\hline Characteristics & Variables & $\%$ \\
\hline \multirow{2}{*}{ Gender } & Male & 45.8 \\
\hline & Female & 54.2 \\
\hline \multirow{4}{*}{ Age range } & $15-24$ & 8.1 \\
\hline & $25-44$ & 32.2 \\
\hline & $45-64$ & 35.4 \\
\hline & 65 and over & 24.3 \\
\hline \multirow{5}{*}{ Level of education } & At least 4 years & 36.46 \\
\hline & Up to 6 years & 16.20 \\
\hline & $7^{\text {th }}-9^{\text {th }}$ grade & 13.42 \\
\hline & $10^{\text {th }}-12^{\text {th }}$ grade & 19.24 \\
\hline & University & 14.68 \\
\hline \multirow{5}{*}{ Profession } & Domestic & 10.89 \\
\hline & Unemployed & 17.97 \\
\hline & Employed & 38.48 \\
\hline & Pensioner & 26.84 \\
\hline & Student & 5.82 \\
\hline \multirow{4}{*}{ Marital status } & Married & 57.97 \\
\hline & Not Married & 25.06 \\
\hline & Divorced & 5.82 \\
\hline & Widowed & 11.14 \\
\hline \multirow{5}{*}{$\begin{array}{l}\text { Household's net monthly } \\
\text { income }\end{array}$} & Less than $€ 500$ & 33.42 \\
\hline & Between $€ 501$ and $€ 1000$ & 42.53 \\
\hline & Between $€ 1001$ and $€ 2500$ & 20.25 \\
\hline & Between $€ 2501$ and $€ 3000$ & 2.53 \\
\hline & Over $€ 3000$ & 1.27 \\
\hline
\end{tabular}

The figures obtained are in accordance with the 2011 population census of Boticas regarding gender, and in accordance with the data of the National Institute of Statistics (INE), which means that the sample is representative of the universe.

Respondents presented a low level of education, seeing as $53 \%$ possessed less than 6 years of schooling. However, up to $65 \%$ had a job (38\%) or was a pensioner $(26 \%)$, revealing low income levels, since the most representative class ranges from 501 to 1000 euros. This corresponds to a lower class and is representative of the number of senior citizens among the municipality's population.

In the present paper, we focused on the questions concerning the perceived attributes of the municipality, in regarding putting into motion a tourism strategy aimed at its economic development. 
Going deep in the analysis, data from the survey applied to the residents was submitted for factor analysis. The results obtained are presented in Tables 3, 4 and 5.

Tab 3. Summary of the results of Boticas' perceived tourist attributes. Source: Self-administrated questionnaire applied to residents between January and May 2016.

\begin{tabular}{|c|c|c|c|c|}
\hline \multicolumn{2}{|c|}{ Measures and test } & Results & \multicolumn{2}{|c|}{ Suitability (see table 1) } \\
\hline \multicolumn{2}{|c|}{ Correlations matrix } & $>0.3$ & & Ok \\
\hline \multicolumn{2}{|l|}{ Determinant value } & 0.001 & & Ok \\
\hline \multicolumn{2}{|l|}{$\mathrm{KMO}$} & 0.905 & & Ok \\
\hline \multicolumn{2}{|c|}{ Barlett's test of sphericity } & 0.000 & & Ok \\
\hline \multicolumn{2}{|c|}{ Cronbach's Alpha } & 0.889 & & Ok \\
\hline \multicolumn{2}{|c|}{ Total explained variance } & $61.98 \%$ & & Ok \\
\hline \multirow{14}{*}{$\begin{array}{l}\text { Measures } \\
\text { Communalities } \\
\text { (principal } \\
\text { components } \\
\text { analysis } \\
\text { extraction } \\
\text { method) }\end{array}$} & Variables & Initial & & Extraction \\
\hline & Popular music & \multicolumn{2}{|l|}{1.000} & .583 \\
\hline & Festivities and events & \multicolumn{2}{|l|}{1.000} & .688 \\
\hline & Gastronomy & \multicolumn{2}{|l|}{1.000} & .575 \\
\hline & Ancestral traditions & 1.000 & & .604 \\
\hline & Museums & 1.000 & & .554 \\
\hline & Churches and chapels & 1.000 & & .556 \\
\hline & Archaeology and history & 1.000 & & .635 \\
\hline & Local handicraft & 1.000 & & .609 \\
\hline & Hunting and fishing & 1.000 & & .735 \\
\hline & Sports & 1.000 & & .660 \\
\hline & Painting and sculpture & -- & & -- \\
\hline & Local products & \multicolumn{2}{|l|}{--} & -- \\
\hline & Natural conditions & \multicolumn{2}{|c|}{--} & -- \\
\hline \multirow[t]{2}{*}{ Measures } & \multirow[t]{2}{*}{ Variables } & \multicolumn{3}{|c|}{ Components } \\
\hline & & Factor 1 & & Factor 2 \\
\hline \multirow{10}{*}{$\begin{array}{l}\text { Rotated matrix } \\
\text { components } \\
\text { (Extraction } \\
\text { method analysis } \\
\text { of main } \\
\text { components. } \\
\text { Rotation } \\
\text { method: } \\
\text { standardization } \\
\text { Varimax with } \\
\text { Kaiser. The } \\
\text { rotation has } \\
\text { coincided in } 3 \\
\text { items). }\end{array}$} & Popular music & & 748 & .152 \\
\hline & Festivities and events & & 787 & .263 \\
\hline & Gastronomy & & 730 & .204 \\
\hline & Ancestral traditions & & 717 & .300 \\
\hline & Museums & & 420 & .614 \\
\hline & Churches and chapels & & 641 & .380 \\
\hline & Archaeology and history & & 389 & .696 \\
\hline & Local handicraft & & 378 & .683 \\
\hline & Hunting and fishing & & 157 & .843 \\
\hline & Sports & & 146 & .799 \\
\hline
\end{tabular}

Three variables (Painting and Sculpture, Local Products and Natural Conditions) were eliminated because they did not meet the criteria (see Table 1). These variables obtained very low commonalities and the set of variables that remain in the group (10) were again submitted for factor analysis.

The perceived tourist attributes of Boticas resulted in two factors. Factor 1 was named "Religion, festivities and traditions" and is composed of 5 variables (Popular music; Festivities and Events; Gastronomy; Ancestral Traditions; Churches and Chapels). Factor 2 was named "Culture and 
Sports" and is also composed of 5 variables (Museums; Archaeology and History; Local Handicraft; Hunting and Fishing; Sports).

Next, the perceived effects of tourism development in the Boticas municipality were analysed (Table 4).

Tab 4. Summary of the results of the perceived effects of tourism development in the Boticas municipality. Source: Self-administrated questionnaire applied to residents between January and May 2016

\begin{tabular}{|c|c|c|c|c|c|c|}
\hline \multicolumn{2}{|l|}{ Measures and test } & Results & \multicolumn{4}{|c|}{ Suitability (see table 1) } \\
\hline \multicolumn{2}{|l|}{ Correlations matrix } & $>0.3$ & \multicolumn{4}{|c|}{ Ok } \\
\hline \multicolumn{2}{|l|}{ Determinant value } & 0.001 & \multicolumn{4}{|c|}{ Ok } \\
\hline \multicolumn{2}{|l|}{$\mathrm{KMO}$} & 0.829 & \multicolumn{4}{|c|}{ Ok } \\
\hline \multicolumn{2}{|c|}{ Barlett's test of sphericity } & 0.000 & \multicolumn{4}{|c|}{ Ok } \\
\hline \multicolumn{2}{|c|}{ Cronbach's Alpha } & 0.828 & \multicolumn{4}{|c|}{ Ok } \\
\hline \multicolumn{2}{|c|}{ Total explained variance } & $67.97 \%$ & \multicolumn{4}{|c|}{ Ok } \\
\hline Measures & \multicolumn{2}{|l|}{ Variables } & \multicolumn{2}{|c|}{ Initial } & \multicolumn{2}{|c|}{ Extraction } \\
\hline \multirow{16}{*}{$\begin{array}{c}\text { Communalities } \\
\text { (principal } \\
\text { components } \\
\text { analysis extraction } \\
\text { method) }\end{array}$} & \multicolumn{2}{|l|}{ Leisure and recreational opportunities } & \multicolumn{2}{|c|}{1.000} & \multicolumn{2}{|c|}{.585} \\
\hline & \multicolumn{2}{|l|}{ Preservation of historic resources } & \multicolumn{2}{|r|}{1.000} & \multicolumn{2}{|r|}{.617} \\
\hline & \multicolumn{2}{|l|}{ Local culture and crafts } & \multicolumn{2}{|c|}{1.000} & & .745 \\
\hline & Contact with different cultures & & & 1.000 & & .617 \\
\hline & Job creation & & & 1.000 & & .604 \\
\hline & Revenues from local economy & & & 1.000 & & .629 \\
\hline & Excessive noise & & & 1.000 & & .785 \\
\hline & Amount of waste & & & 1.000 & & .857 \\
\hline & Criminality & & & 1.000 & & .781 \\
\hline & Difficulty in preserving values, customs & רd traditions & & 1.000 & & .552 \\
\hline & Residents' income & & & 1.000 & & .692 \\
\hline & Community self-esteem & & & 1.000 & & .647 \\
\hline & Quality of life & & & 1.000 & & .727 \\
\hline & Quality of public services & & & -- & & -- \\
\hline & Price increase & & & -- & & -- \\
\hline & Increase in investments & & & -- & & -- \\
\hline Measures & Variables & & & ompon & nts & \\
\hline & & & Factor 1 & Facto & & Factor 3 \\
\hline & Leisure and recreational opportunities & & .691 & & & .327 \\
\hline $\begin{array}{l}\text { components } \\
\text { (Extraction method }\end{array}$ & Preservation of historic resources & & .756 & & & .214 \\
\hline analysis of main & Local culture and crafts & & .850 & & 12 & .101 \\
\hline components. & Contact with different cultures & & .779 & & 91 & .030 \\
\hline Rotation method: & Job creation & & .719 & & & .295 \\
\hline Varimax with Kaiser. & Revenues from local economy & & .772 & & 21 & .133 \\
\hline The rotation has & Excessive noise & & .133 & & 75 & -.053 \\
\hline $\begin{array}{l}\text { coincided in } 3 \\
\text { items). }\end{array}$ & Amount of waste & & .088 & & 21 & -.023 \\
\hline & Criminality & & .037 & & 75 & .120 \\
\hline & Difficulty in preserving values, custom & רd traditions & -.056 & & 32 & .334 \\
\hline & Residents' income & & .263 & & & .784 \\
\hline & Community self-esteem & & .218 & & 2 & .768 \\
\hline & Quality of life & & .194 & & 7 & .827 \\
\hline
\end{tabular}

Three variables (Quality of Public Services, Price Increase and Increase in Investments) were eliminated because they did not meet the criteria (see Table 1). These variables obtained very low commonalities and the set of variables that remain in the group (13) were again submitted for factor analysis.

Using the data regarding the perceived effects of tourism development in Boticas, three factors were obtained. Factor 1 was named "Generated Opportunities" and is composed of 6 variables 
(Leisure and Recreational Opportunities; Preservation of Historic Resources; Local Culture and Crafts; Contact with Different Cultures; Job Creation; Revenues from Local Economy). Factor 2 was named "Environmental, Social and Cultural Conditions" and is composed of 4 variables (Excessive Noise; Amount of Waste; Criminality; Difficulty in Preserving Values, Customs and Traditions). Finally, Factor 3 was named "Welfare" and is composed of 3 variables (Residents' Income; Community Self-esteem; Quality of Life).

In Table 5 we show the results related to the perceived global image of Boticas.

Tab 5. Summary of the perceived global image of Boticas. Source: Self-administrated questionnaire applied to residents between January and May 2016

\begin{tabular}{|c|c|c|c|c|c|c|}
\hline \multicolumn{2}{|c|}{ Measures and test } & Results & \multicolumn{4}{|c|}{ Suitability (see table 1) } \\
\hline \multicolumn{2}{|l|}{ Correlations matrix } & $>0.3$ & \multicolumn{4}{|c|}{ Ok } \\
\hline \multicolumn{2}{|l|}{ Determinant value } & 0.003 & \multicolumn{4}{|c|}{ Ok } \\
\hline \multicolumn{2}{|l|}{$\mathrm{KMO}$} & 0.850 & \multicolumn{4}{|c|}{$\mathrm{Ok}$} \\
\hline \multicolumn{2}{|c|}{ Barlett's test of sphericity } & 0.000 & \multicolumn{4}{|c|}{ Ok } \\
\hline \multicolumn{2}{|l|}{ Cronbach's Alpha } & 0.867 & \multicolumn{4}{|c|}{ Ok } \\
\hline \multicolumn{2}{|c|}{ Total explained variance } & $64.5 \%$ & \multicolumn{4}{|c|}{ Ok } \\
\hline Measures & \multicolumn{2}{|l|}{ Variables } & \multicolumn{2}{|l|}{ Initial } & \multicolumn{2}{|c|}{ Extraction } \\
\hline \multirow{13}{*}{$\begin{array}{l}\text { Communalities } \\
\text { (principal } \\
\text { components } \\
\text { analysis } \\
\text { extraction } \\
\text { method) }\end{array}$} & \multicolumn{2}{|l|}{ Landscape } & \multicolumn{2}{|c|}{1.000} & \multicolumn{2}{|c|}{.649} \\
\hline & \multicolumn{2}{|l|}{ Architectural heritage } & \multicolumn{2}{|c|}{1.000} & \multicolumn{2}{|r|}{.580} \\
\hline & \multicolumn{2}{|l|}{ Historic sites } & \multicolumn{2}{|c|}{1.000} & \multicolumn{2}{|r|}{.573} \\
\hline & \multicolumn{2}{|l|}{ Cultural programme } & 1.0 & & & .628 \\
\hline & Disclosure of cultural events & & 1.0 & & & .651 \\
\hline & Quality hotel offer & & 1.0 & & & .612 \\
\hline & Restaurants and catering services & & 1.0 & & & .593 \\
\hline & Signage and tourist information & & 1.0 & & & .581 \\
\hline & $\begin{array}{l}\text { Public services (schools, health ce } \\
\text { etc.) }\end{array}$ & centres, & 1.0 & & & .679 \\
\hline & Public transportation & & 1.0 & & & .677 \\
\hline & Road infrastructures & & 1.0 & & & .714 \\
\hline & Safety & & 1.0 & & & .751 \\
\hline & Cleanliness & & 1.0 & & & .677 \\
\hline Measures & Variables & & & m & jonents & \\
\hline & & & Factor 1 & & actor 2 & Factor 3 \\
\hline Rotated matrix & Landscape & & .590 & & -.195 & .512 \\
\hline components & Architectural heritage & & .731 & & -.042 & 209 \\
\hline (Extraction & Historic sites & & .714 & & .067 & .243 \\
\hline method analysis & Cultural programme & & .744 & & .223 & .156 \\
\hline of main & Disclosure of cultural events & & .742 & & .311 & .068 \\
\hline components. & Quality hotel offer & & .720 & & .298 & .065 \\
\hline Rotation method: & Restaurants and catering services & & .718 & & .259 & -.100 \\
\hline standardization & Signage and tourist information & & .338 & & .683 & .009 \\
\hline $\begin{array}{l}\text { Varimax with } \\
\text { Kaiser. The }\end{array}$ & $\begin{array}{l}\text { Public services (schools, health co } \\
\text { etc.) }\end{array}$ & centres, & .151 & & .782 & .210 \\
\hline rotation has & Public transportation & & .185 & & .799 & .063 \\
\hline coincided in 3 & Road infrastructures & & -.012 & & .750 & .390 \\
\hline & Safety & & .188 & & .196 & .823 \\
\hline & Cleanliness & & .107 & & .359 & .733 \\
\hline
\end{tabular}

All variables met the criteria established in Table 1, so the original set of variables remained (13). Three factors that pertained to the perceived global image of Boticas were obtained. Factor 1 was named "Tourism Resources" and is composed of 7 variables (Landscape; Architectural Heritage; Historic Sites; Cultural Programme; Disclosure of Cultural Events; Quality Hotel Offer; Restaurants and Catering Services). Factor 2 was named "Public Services and Tourism Support" and is composed of 4 variables (Signage and Tourist Information; Public Services; Public Transportation; Road Infrastructures). And, finally, Factor 3 was named "Public Services and Tourism Support" and is composed of 2 variables (Safety; Cleanliness). 
Concerning the perception of the effects of tourism development, the respondents pointed out expectations such as job creation, preservation of historic resources or improvement of the quality of life. Residents also identified negative aspects, such as the possible increase of criminality, waste and noise.

The aspects related to economic issues, such as price increase and investments, which may affect residents (positively and negatively) seem to not fit into the set of variables considered by residents. This implies that important questions about the economic potential of tourism development were not contemplated in the possible effects identified by the respondents. Residents have shown good expectations about the effects of tourism, but exclude direct economic effects other than job creation.

As said earlier, one of the questions this study sought to answer was the following: How do residents perceive the resources and attributes of the Boticas municipality?

Nature, gastronomy and local traditions were mostly valued despite some of them being underexplored until now. Gastronomic services were perceived as one of the main restriction factors, that is, a factor to which attention must be given.

As for the tourist attributes of Boticas, the respondents have mainly emphasised the importance of religion, popular festivities and traditions, besides culture and sports. They have claimed that local products and natural resources were important, however, they were not considered in the final set of variables. Thus, they were not taken into account in the final set of tourist attributes. It should also be noted that in the case of Boticas' global image, all variables were considered important; therefore, none of the proposals were initially removed from the group.

\subsubsection{Qualitative approach}

The interviews were undertaken in 2016 with 25 local and regional stakeholders, of whom 16 were male and 9 were female. In terms of their levels of education, 14 had attended university education, with a predominance of undergraduate degrees $(n=8)$. The majority of the participants occupied functions as heads (presidents) of institutions/organisations $(n=14)$ (see Table 6).

Tab 6. The main socio-demographic characteristics of those individuals who integrated the stakeholders interviewed group. Source: Authors' own elaboration, based on the semi-structured interview conducted between July and September 2016.

\begin{tabular}{|l|l|c|}
\hline \multicolumn{1}{|c|}{ Characteristics } & \multicolumn{1}{|c|}{ Variables } & Number \\
\hline \multirow{4}{*}{ Gender } & Male & 16 \\
\cline { 2 - 3 } & Female & 9 \\
\hline \multirow{5}{*}{ Level of education } & At least 4 years & 0 \\
\cline { 2 - 3 } & Up to 6 years & 1 \\
\cline { 2 - 3 } & $7^{\text {th }}-9^{\text {th }}$ grade & 3 \\
\cline { 2 - 3 } & $10^{\text {th }}-12^{\text {th }}$ grade & 7 \\
\cline { 2 - 3 } & University & 14 \\
\hline \multirow{5}{*}{ Occupation } & Owner & 1 \\
\cline { 2 - 3 } & Secretary & 1 \\
\cline { 2 - 3 } & Manager & 1 \\
\cline { 2 - 3 } & Tecnical assistent & 1 \\
\cline { 2 - 3 } & Senior technician & 1 \\
\cline { 2 - 3 } & Director & 14 \\
\cline { 2 - 3 } & Council woman of tourism & 1 \\
\cline { 2 - 3 } & Head of the institution/organization (President) & 1 \\
\hline
\end{tabular}

Similar to the residents' perceptions, the stakeholders' interviews revealed that they believed that tourism is currently very relevant to local and regional competitiveness and can be a driver for economic development. Most of them perceived Nature as the key to tourism development, 
followed by gastronomy and culture, and understood the need to preserve this set of attributes. However, stakeholders have shown difficulty in identifying the resources that were properly explored. Despite this, the perception that the quality of the tourism services provided by Boticas could be classified as medium, but could also improve, and was consensual.

In contrast with residents' perceptions, when stakeholders were asked about the population's readiness to deal with the tourism industry, opinions were split in half. Most recognised that they would need to create a true "culture addressing tourism activity", once the territory was perceived to be well-equipped in terms of public services.

Opinions were also divided in what concerns touristic business and stakeholders' connection to it. In the meantime, stakeholders' perceptions about the main drivers for Boticas' tourism development seemed to be optimistic. Some of them received support from Hospitality, Nature, Gastronomy and Local Products grants (Figure 4). Similar to the residents' perceptions, major gaps were identified in areas such as road infrastructures, tourist information, marketing of cultural events and the quality of catering services.

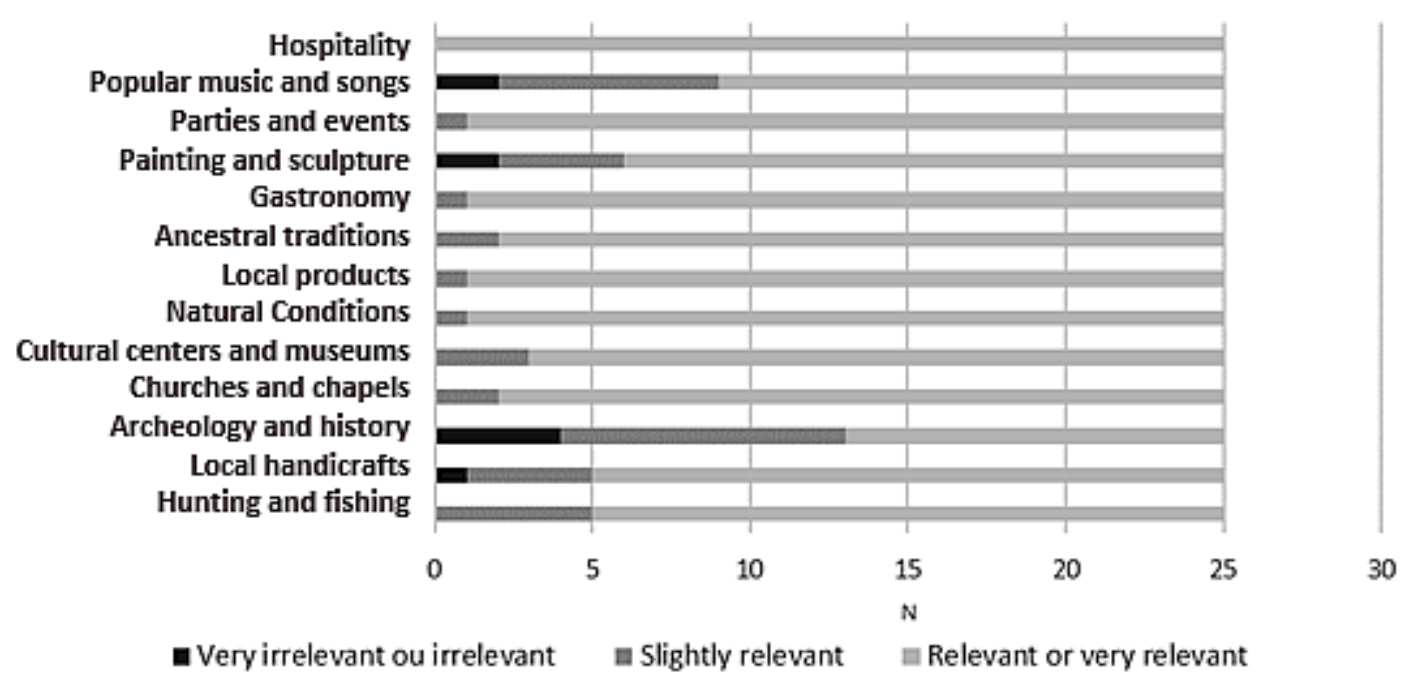

Fig 4. Stakeholders' perceptions of main drivers for tourism development. Source: Interviews conducted with local and regional stakeholders between July and September 2016.

An area in which local and regional agents have revealed a duality of responses was the one related to the preparation of the municipality inhabitants to properly receive more tourists. The local population is surely hospitable but, nevertheless, there is still significant inexperience in the way the tourist is received. With this in mind, it was pointed out that a "culture towards tourism" was needed and this could be reached by increasing the effort in education.

In 2016, these interviewees perceived environmental tourism (that is, Nature) as the most relevant Boticas attribute, although its gastronomy and the cultural components were also seen as relevant. Although gastronomy was indicated as a potential tourist attraction, residents, as well as qualified local and regional actors who inquired, mentioned that catering services were limited in number and availability. The difficulty in creating new ventures was also identified by local and regional actors for two main reasons, namely, the lack of entrepreneurship spirit; and the age of the residents.

There was a duality of responses on the part of local and regional agents when collecting their perspectives on whether the population and the municipality were prepared to receive more tourists. The need to educate the population was also identified. Additionally, it was mentioned that the population is hospitable, but, nevertheless, there was still a lot of inexperience in the way tourists were received, i.e., a "culture for tourism" was lacking.

Some local and regional actors found it difficult to identify the resources that were best exploited. Those who identified them focused mostly on religious festivals, historical staging, and 
gastronomy. They identified an average quality level of tourism services provided in Boticas, but they also expressed the belief that there is a capacity of gaining a high level of services.

All local and regional actors believe that Boticas is a safe place to live, as well as a territory endowed with important historical sites and an attractive countryside. Nevertheless, the public transport system, the efficiency of other public services, the road infrastructure, signage and tourist information, the promotion and existence of cultural events, and the quality of catering services were elements where less positive perception was seen. These results are similar to those found in the survey given to the residents.

\section{Conclusions and Political Recommendations for the Future}

To attain a more sustainable development path, tourism development is, in many cases, the key instrument. This way, the diversification and revitalisation of some rural communities can be achieved. This has to do with the fact that the tourism industry requires the contribution of various fields of activity, starting with transportation to accommodation and food services, leisure and cultural activities, among several others, as underlined by McEwan (2005) and Williams, Hall and Lew (2014), and many other authors. Assuming this, the current paper sought mainly to approach the integrated view held by residents and local and regional qualified stakeholders of Boticas toward the resources and attributes of their territory, as well as how they perceived their tourism industry as a potential contributor to local development.

While approaching this topic directly, the major concern of the research team was to get answers to two questions: i) how do the local and regional stakeholders perceive the resources and attributes of the Boticas municipality? and, ii) what kind of planning strategies of local and regional development can/should be proposed based on a more collaborative and participative way of decision-making?

Based on recent development theories and on empirical evidence, we strongly believe that the starting point for that development cannot be anything but their endogenous resources (landscape, local know-how, traditional festivities, built heritage, natural and cultural resources), together with the mobilisation of local stakeholders and the general population. As claimed, participative/collaborative planning is thought to be essential in order to achieve sustainable development.

When cross-referencing the data obtained by the research team, the importance of Boticas' natural and material heritage is undeniable. The natural heritage, together with the landscape's rural characteristics, allows the discovery of places of interest for those seeking rest and leisure spots, as noted by the residents and confirmed by the inventory the research team compiled throughout their fieldwork.

From the inventory of cultural resources undertaken, we could conclude that the resources with greater tourist potential are elements of religious built heritage, to which we should add intangible heritage, namely annual religious festivals that involve the entire community and that are key elements of local identity. However, there is work to be done in order to maintain and protect these heritage resources.

Reharding Boticas' perceived tourist attributes, the survey conducted with the residents highlighted two main drivers (structural factors): "Religion, festivities and traditions" and "Culture and Sports". This "view" is quite consistent with the resources inventoried, even if some doubts arose, concerning the perceptions kept by residents on the potential impacts of the tourism industry and on their preparation to deal with the potential increase in the arrival of tourists. Regarding this last aspect, one can always expect that the necessary measures to technically and culturally prepare the local population for this challenge will require time.

However, considering that the religious heritage may be one of the destination's main drivers, the diagnosis of the territory's heritage resources revealed that it also presented serious problems in terms of restoration. The religious festivities were identified by residents as having great impact and great potential for the development of the tourism sector. 
Similar to that of the residents, qualified stakeholders' interviews revealed that they believe that tourism is very relevant to achieve local and regional competitiveness and can be a driver for the economic development of Boticas. Most of them perceived nature as the main asset, together with gastronomy and culture. However, stakeholders have shown difficulty in identifying the resources that were properly explored.

To turn Boticas and the region into a tourism destination, major gaps need to be filled such as road infrastructures, tourist information, marketing of cultural events and the quality of catering services. This should not be surprising, if we keep in mind the territory's agricultural background and the embryonic stage of development the tourism industry finds itself in. There is always a beginning for everything. Looking at the resources available and the commitment towards developing the industry shown by common residents and major stakeholders, the potential is definitely there.

This research is a first contribution to establishing a tourism strategy in the territory under scrutiny: Boticas, in the Northeastern Portugal. After inventorying resources and verifying the perceptions and commitments revealed by the local population and other stakeholders, much more must be done. Aiming to follow a sustainable path, a strategic plan needs to bring together public authorities and general stakeholders, including the residents, and follow a participative process. That is the only way to guarantee commitment from those actors to the strategy, as underlined by the literature on the issue (see: Butler, 1999; Aas, Ladkin and Fletcher, 2005; Hottola, 2009).

One major limitation of the research conducted came from the initial and insufficient level of knowledge of the territory by the research team, which made both establishing the structure of the survey implemented with residents and the inventory of cultural resources difficult. In addition, the data analysis conducted in this paper should be observed as a first approach to this data, that is, other techniques could be used and will certainly be used in future exploration of the same data set.

\section{Acknowledgments}

This work has the financial support of the Project Lab2PT - Landscapes, Heritage and Territory Laboratory - AUR/04509 and FCT through national funds and when applicable of the FEDER cofinancing, in the aim of the new partnership agreement PT2020 and COMPETE2020 - POCI 01 0145 FEDER 007528.

\section{Academic references}

[1] Aas, C., Ladkin, A. \& Fletcher, J. (2005). Stakeholder collaboration and heritage management. Annals of Tourism Research 32(1), 28-48. DOI: 10.1016/j.annals.2004.04.005.

[2] Abellán, F. C. (2008). Turismo Rural y desarrollo local: relaciones, desafíos, propuestas. In Abellán, F. C., ed., Turismo rural y desarrollo local (pp. 11-28). Sevilla/Cuenca: Ediciones de la Universidad Castilla-la-Mancha.

[3] Agarwal, S., Rahman, S. \& Errington, A. (2009). Measuring the determinants of relative economic performance of rural areas. Journal of Rural Studies, 25(3), 309-321. DOI: 10.1016/j.jrurstud.2009.02.003.

[4] Bartlett, M. S. (1951). A further note on tests of significance in factor analysis. British Journal of Psychology, 4(1), 1-2. DOI: 10.1111/j.2044-8317.1951.tb00299.x.

[5] Bosworth, G., Annibal, I., Carroll, T., Price, L., Sellick, J. \& Shepherd, J. (2015). Empowering Local Action through Neo-Endogenous Development; The Case of LEADER in England. Sociologia Ruralis 56(3), 427-449. DOI: 10.1111/soru.12089.

[6] Butler, R. (1999). Sustainable Tourism: A State-of-the-Art Review. Tourism Geographies 1(1), 7-25. DOI: 10.1080/14616689908721291. 
[7] Campbell, D.T. \& Fiske, D.W. (1959). Convergent and discriminant validation by the multitrait-multimethod matrix. Psychological Bulletin 56(2), 81-105. DOI: $10.1037 / \mathrm{h} 0046016$.

[8] Cano, M., Garzón, E. \& Sánchez-Soto, P. J. (2013). Preservation and Conservation of Rural Buildings as a Subject of Cultural Tourism: A Review Concerning the Application of New Technologies and Methodologies. Journal of Tourism \& Hospitality 2(2), 1-13. DOI: 10.4172/2167-0269.1000115.

[9] Cánoves, G., Villarino, M., Priestley, G. K. \& Blanco, A. (2004). Rural tourism in Spain: an analysis of recent evolution. Geoforum 35(6), 755-769. DOI: 10.1016/j.geoforum. 2004.03.005.

[10] Crosby, A. (2007). Re-inventando el turismo rural: gestión and desarrollo. Barcelona: Laertes.

[11] Ehrlich, K. (2010). Proyecciones del turismo rural en Europa. In Jimenez Moreno, F. J. \& Melgosa Arcos, F. J., eds. Estudios del turismo rural y cooperación entre Castilla, Léon y Portugal (pp. 11-28). Salamanca: Ediciones Universidad de Salamanca.

[12] Fonte, M. (2008). Knowledge, food and place. A way of producing, a way of knowing. Sociologia Ruralis, 48(3), 200-222. DOI: 10.1111/j.1467-9523.2008.00462.x.

[13] Gebremedhin, T. G. \& Tweeten, L. G. (1994). Research methods and communication in the social sciences. London: ABC-CLIO.

[14] Hall, C. M. (2008). Tourism planning: policies, processes and relationships. $3^{\text {rd }}$ ed. Essex: Pearson Education.

[15] Hall, D., Mitchell, M. \& Roberts, L. (2016). Tourism and the countryside: dynamic relationships. In Hall, D., Roberts, L. \& Mitchell, M., eds. New Directions in Rural Tourism (pp. 3-15). New York: Routledge.

[16] Harvey, D. (1969). Explanation in geography. London: Edward Arnold.

[17] Haven-Tang, C. \& Sedgley, D. (2014). Partnership working in enhancing the destination brand of rural areas: A case study of Made in Monmouthshire, Wales, UK. Journal of Destination Marketing \& Management 3(1), 59-67. DOI: 10.1016/j.jdmm.2013.12.001.

[18] High, C. \& Nemes, G. (2007). Social learning in LEADER: Exogenous, endogenous and hybrid evaluation in rural development. Sociologia Ruralis 47(2), 103-119. DOI: 10.1111/j.1467-9523.2007.00430.x.

[19] Hottola, P., ed. (2009). Tourism strategies and local responses in Southern Africa. Wallingford: CABI. DOI: 10.1079/9781845935085.0000.

[20] Hussein, A. (2015). The use of triangulation in social sciences research: Can qualitative and quantitative methods be combined? Journal of Comparative Social Work 4(1), 1-12.

[21] Isserman, A. M., Feser, E., \& Warren, D. E. (2009). Why some rural places prosper and others do not. International Regional Science Review 32(3), 300-342. DOI: $10.1177 / 0160017609336090$.

[22] Jackson, L. A. (2008). Residents' perceptions of the impacts of special event tourism. Journal of Place Management and Development 1(3), 240-255. DOI: 10.1108/17538330810911244.

[23] Kitchen, L. \& Marsden, T. (2009). Creating Sustainable Rural Development through Stimulating the Eco-economy: Beyond the Eco-economic Paradox? Sociologia Ruralis, 49(3), 273-294. DOI: 10.1111/j.1467-9523.2009.00489.x.

[24] Kneafsey, M. (2001). Rural cultural economy: Tourism and social relations. Annals of Tourism Research 28(3), 762-783. DOI: 10.1016/S0160-7383(00)00077-3.

[25] Landford, C. (2009). Managing for sustainable tourism: a review of six cultural World Heritage Sites. Journal of Sustainable Tourism 17(1), 53-70. DOI: 10.1080/09669580802159719. 
[26] Leiper, N. (1979). The Framework of Tourism: Towards a Definition of Tourism, Tourist, and the Tourism Industry. Annals of Tourism Research 6(4), 390-407. DOI: 10.1016/01607383(79)90003-3.

[27] Lessard-Hébert, M., Goyette, G. \& Boutin, G. (2012). Investigação qualitativa: Fundamentos e práticas. Lisboa, Instituto Piaget.

[28] Lopes, H. (2016). O turismo como alavanca de desenvolvimento de áreas rurais: o estudo de caso do município de Boticas [Master Dissertation]. Braga: University of Minho.

[29] Lopes, H., Remoaldo, P. C., Ribeiro, V., Ribeiro, J. C. \& Silva, S. (2016). The creation of a new tourist destination in low density areas: the Boticas case. Journal of Spatial and Organizational Dynamics 4(2), 118-131.

[30] McEwan, C. (2005). Geography, culture and global change. In Daniels et al., ed., An introduction to Human Geography: issues for the $21^{\text {st }}$ century, $2^{\text {nd }}$ ed. (pp. 265-283). Essex: Pearson Education Limited.

[31] Molina-Azorín, J. F. \& Font, X. (2016). Mixed methods in sustainable tourism research: an analysis of prevalence, designs and application in JOST (2005-2014). Journal of Sustainable Tourism 24(4), 549-573. DOI: 10.1080/09669582.2015.1073739.

[32] Murphy, P. (1985). Tourism: A Community Approach. London: Methuen.

[33] Negrut, L., \& Vlad, S. (2016). Perspectives of Rural Tourism Development in Caras-Severin county. Lucrări Științifice Management Agricol 17(4), 82-89.

[34] Nunkoo, R., Smith, S. L. \& Ramkissoon, H. (2013). Residents' attitudes to tourism: A longitudinal study of 140 articles from 1984 to 2010. Journal of Sustainable Tourism 21(1), 5-25. DOI: 10.1080/09669582.2012.673621.

[35] Nunnally, J. C. (1978). Psychometric theory. $2^{\text {nd }}$ ed. New York: McGraw-Hill.

[36] Nylander, M. (2001). National Policy for rural tourism: the case of Finland. In Roberts, L. and Hall, D., ed., Rural Tourism and recreation: principles to practices (pp. 77-85). New York: Cabi publishing.

[37] Oppermann, M. (2000). Triangulation - a methodological discussion. International Journal of Tourism Research, 2(2), 141-146. DOI: 10.1002/(SICI)1522-1970(200003/04)2:2<141::AIDJTR217>3.0.CO;2-U.

[38] Pérez López, C. (2005). SPSS advanced statistical methods. Madrid: Thomson.

[39] Radac, A. B., Csosz, I., Iulianamerce, I., Matias, C. G., \& Dobra, C. I. (2012). The benefits of rural tourism. In sustainable rural development. International scientific symposium, 14(4), 369-372. Neidentifikovatelné a zmatené

[40] Ray, C. (1998). Territory, structures and interpretation - Two case studies of the European Union's LEADER I programme. Journal of Rural Studies 14(1), 79-87. DOI: 10.1016/S07430167(97)00039-9.

[41] Ray, C. (2006). Neo-endogenous rural development in the EU. In Cloke, P., Marsden, T. \& Mooney, P., ed., Handbook of rural studies (pp. 278-291). London, Thousand Oaks and New Delhi: Sage Publications.

[42] Remoaldo, P. C. \& Cadima Ribeiro, J. (2015). Holistic approach, tourism. In Jafari, J. \& Xiao, $\mathrm{H}$., eds., Encyclopedia of Tourism (pp. 430-431). Cham: Springer International Publishing, DOI: 10.1007/978-3-319-01669-6_477-1.

[43] Rivero, M. S., Martín, J. M. S. \& Gallego, J. I. R. (2016). Methodological approach for assessing the potential of a rural tourism destination: An application in the province of Cáceres (Spain). Current Issues in Tourism 19(11), 1084-1102. DOI: $10.1080 / 13683500.2014 .978745$. 
[44] Sánchez-Fernández, M. D. (2014). La teoría institucional y la responsabilidad social corporativa en el sector hotelero de la eurorregión Galicia-Norte de Portugal [Doctoral dissertation]. Universidade da Coruña.

[45] Sekaran, U. (2003). Research methods for business: A skill approach. Hoboken, NJ.: John Willey and Sons, Inc.

[46] Sharma, B. \& Dyer, P. (2009). An investigation of differences in residents' perceptions on the Sunshine Coast: tourism impacts and demographic variables. Tourism Geographies 11(2), 187-213. DOI: 10.1080/14616680902827159.

[47] Shaw, G. \& Williams, A. M. (1994). Critical Issues in Tourism. Oxford: Blackwell.

[48] Siebert, R., Laschewski, L. \& Dosch, A. (2008). Knowledge dynamics in valorising local nature. Sociologia Ruralis 48(3), 223-239. DOI: 10.1111/j.1467-9523.2008.00464.x.

[49] Silva, A. S. \& Pinto, J. M., eds., (1987). Metodologia das Ciências Sociais, 2nd ed., Porto: Edições Afrontamento.

[50] Stylidis, D. (2016). The Role of Place Image Dimensions in Residents' Support for Tourism Development. International Journal of Tourism Research 18(2), 129-139. DOI: 10.1002/jtr.2039.

[51] Vareiro, L., Remoaldo, P. C. \& Cadima Ribeiro, J. A. (2013). Residents' perceptions of tourism impacts in Guimarães (Portugal): a cluster analysis. Current Issues in Tourism 16(6), 535-551. DOI: 10.1080/13683500.2012.707175.

[52] Verdu Jover, A. J. (2002). Relación entre flexibilidad y desempeño organizativo: una aproximación desde la perspectiva de la gestión de la calidad total. Alicante: Universidad Miguel Hernández.

[53] Wang, C. H. (2005). Constructing multivariate process capability indices for short-run production. International Journal of Advanced Manufacturing Technology 26(11-12), 13061311. DOI: 10.1007/ s00170-004-2397-8.

[54] Williams, A., Hall, C. M. \& Lew, A. (2014). Theoretical and methodological challenges for tourism. In Lew, A., Hall, C. M. \& Williams, A., eds., Theoretical and methodological challenges for tourism (pp. 625-634). London: Blackwell.

[55] Wilson, S., Fesenmaier, D. R., Fesenmaier, J. \& van Es, J. C. (2001). Factors for success in rural tourism development. Journal of Travel Research 40(2), 132-138. DOI: $10.1177 / 004728750104000203$.

[56] Woods, M. (2007). Engaging the global countryside: globalization, hybridity and the reconstitution of rural place. Progress in Human Geography 31(4), 485-507. DOI: $10.1177 / 0309132507079503$.

[57] Woods, M. (2011). Rural (Key ideas in geography). New York: Routledge.

[58] Wubneh, M. A. (1987). Multivariate analysis of socio-economic characteristics of urban areas in Ethiopia. African Urban Quaterly 2(4), 425-433.

Other sources

[59] Carta de Burra (1999). Access $25^{\text {th }}$ January, 2017

http://www.culturanorte.pt/fotos/editor2/1999-

carta_de_burra_para_lugares_de_significado_cultural-icomos_australia.pdf.

[60] Carta de Veneza (1964). Access 25 th January, 2017

http://www.fmnf.pt/Upload/Cms/Archive/CartadeVeneza1964.pdf.

[61] Icomos, (2007), Icomos Ename Charter for the Interpretation of Cultural Heritage Sites, Icomos, Paris. Acedido em http://www.enamecharter.org/downloads.html. 
[62] INE, I. P. (2014). Anuário Estatístico da Região Norte - 2013. Lisboa: Instituto Nacional de Estatística.

[63] Moreno, L. (2008). A promoção e a oferta de turismo em áreas de baixa densidade. Portugal no contexto europeu [Paper presented at the I Seminário de Turismo e Planeamento do Território]. Lisbon.

[64] World Tourism Organization. European Commission (2013). Sustainable Tourism for Development. Guidebook: Madrid. 